\title{
NÖI HALLGATÓK SZÁMÁNAK NÖVELÉSE A MÉRNÖKI KARON
}

\author{
Zsótér Brigitta - Gál József
}

\begin{abstract}
Absztrakt: A Szegedi Tudományegyetem Mérnöki Karán a 2018. november 1. és 2019. január 31. közötti időszakban kétszer is megrendeztük a „A természettudományos, mérnöki szakok területén a női hallgatók számának növekedése" című eseményt, amely az EFOP-3.4.3-16-2016-00014 azonosító számú, „A Szegedi Tudományegyetem oktatási és szolgáltatási teljesítményének innovatív fejlesztése a munkaerőpiaci és a nemzetközi verseny kihívásaira való felkészülés jegyében" című pályázat AP1 Hallgatói diploma-szerzést segítő szolgáltatások; AP1_MK Lemorzsolódást csökkentő program kifejlesztése az MK-n az MTMI területeken c. alprojekt keretén belül került megvalósításra. A rendezvények célja az volt, hogy a mérnöki tudományokat és a Mérnöki Kar képzéseit népszerüsítse a középiskolás diáklányok körében, ezáltal a mérnökhallgató lányok arányát növelje a jövőben a karon.
\end{abstract}

\begin{abstract}
The Faculty of Engineering, University of Szeged organized twice in the period between 1 November, 2018 and 31 January, 2019 an event called „Increasing the number of female students in the field of natural sciences and engineering", which has been accomplished as a subproject - called AP 1 Services to help students graduate; AP1_MK Developing a program at the Faculty of Engineering to reduce dropout in STEM - of an application EFOP-3.4.3-16-2016-00014 with the title "The innovative development of the educational and service performances of University of Szeged in order to get prepared for the challenges of the labour market and the international competition". The purpose of the events was to make engineering sciences and trainings of the Faculty of Engineering more appealing for girls in secondary schools, thus increasing the number of female students at the Faculty in the future.
\end{abstract}

Kulcsszavak: Mérnöki Kar, képzési választék, laborok látogatása, női hallgatók számának növelése

Keywords: Faculty of Engineering, trainings, visits to laboratories, increasing the number of female students

\section{Bevezetés}

Egy felsőoktatási intézmény életében kiemelt fontosságú a beiskolázás kérdése. Kun András kutatási eredményei (2018) igazolják, hogy a jelentkezőket, amikor az intézményválasztás kritériumairól döntenek (tudatosan vagy sem) valamilyen mértékben befolyásolhatja, hogy milyen kulturális közegbe szeretnének tartozni. Tehát az intézmény imázsa a javarészt meghatározó. Az imázs kialakításának egyik módja lehet a digitális kultúra eszközeinek igénybevétele (Fabulya, 2004; Hampel, 2018), így például az intézmény honlapja (Kiss-Kun, 2018), közösségi oldala is. Továbbá sokat számít, hogy a képzés során megkapott ismeretekkel milyen esélyekkel lépnek majd ki a munkaeröpiacra (Kiss et al., 2017) és mennyire gyorsan tudnak elhelyezkedni (Kiss-Barizsné, 2016). A tanítási módszerek (Mocan et al., 2016) az iskolaválasztás (Turi et al., 2016) során csak jóval ezek után következnek a fontossági sorrendben.

A sikeres beiskolázás, sőt mi több a női hallgatói arány jövőbeli növelése érdekében a Szegedi Tudományegyetem Mérnöki Karán a 2018. november 1. és 2019. január 31. közötti időszakban kétszer is megrendezésre került a „A természettudományos, mérnöki szakok területén a női hallgatók számának 
növekedése" címü esemény, amely az EFOP-3.4.3-16-2016-00014 azonosító számú, „A Szegedi Tudományegyetem oktatási és szolgáltatási teljesítményének innovatív fejlesztése a munkaerőpiaci és a nemzetközi verseny kihívásaira való felkészülés jegyében" címủ pályázat AP1 Hallgatói diploma-szerzést segítő szolgáltatások; AP1_MK Lemorzsolódást csökkentő program kifejlesztése az MK-n az MTMI területeken c. alprojekt keretén belül került megvalósításra.

\section{Anyag és módszer}

A sikeres rendezvének lebonyolítása érdekében meg kellett terveznünk a szakmai programokat, megírni a részletes forgatókönyvet, előkészíteni és kiküldeni a meghívót. A rendezvény szervezése során felvettük és folyamatosan tartottuk a kapcsolatot azon kollégákkal és segítő hallgatókkal, aki a lebonyolításban részt vettek. Középiskolás lányokat toboroztunk, akiknek szóltak a rendezvényeink, a projekt. Felkerestük a Bagó Ildikót, a szegedi Eötvös József Gimnázium tanárát és a Soroptimist Club Szeged alelnökét, Baranyi Irént, akik segített érdeklődő középiskolás lányokat toborozni az eseményekre.

\section{Eredmények és értékelésük}

A rendezvények célja, hogy a mérnöki tudományokat és a Mérnöki Kar képzéseit népszerüsítsék a középiskolás diáklányok körében, ezáltal a mérnökhallgató lányok arányát növeljék a jövőben a karon. A következő fotón az érdeklődők fogadását láthatjuk (1. ábra).

\section{1. ábra: Az érdeklődő középiskolások fogadása}

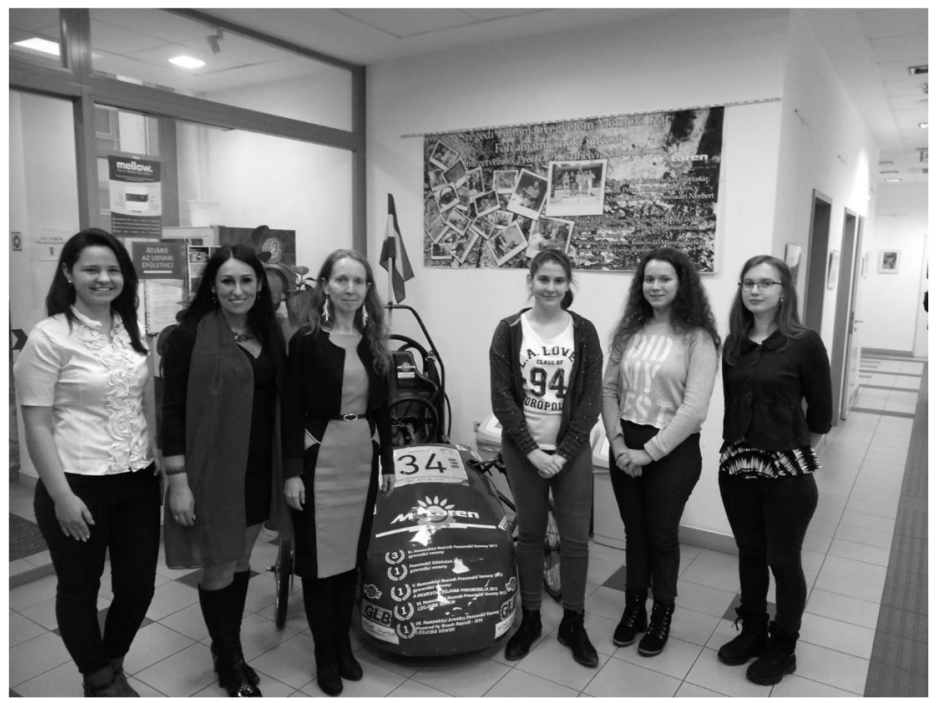

Forrás: A szerzők saját készítésű fényképe.

A rendezvény részvevői betekinthettek a kar képzési választékába, majd tájékoztatást kaptak az SZTE MK Hallgatói Önkormányzat által szervezett programokról, valamint a hallgatói mobilitásról (pl. CEEPUS) külföldi egyetemekre 
Laurinyecz Nórától, a HÖK alelnökétől, aki a hallgatói mobilitásban már többszörösen részt vett (2. ábra).

2. ábra: Tájékoztató a Hallgatói Önkormányzat programjairól és hallgatói mobilitásról

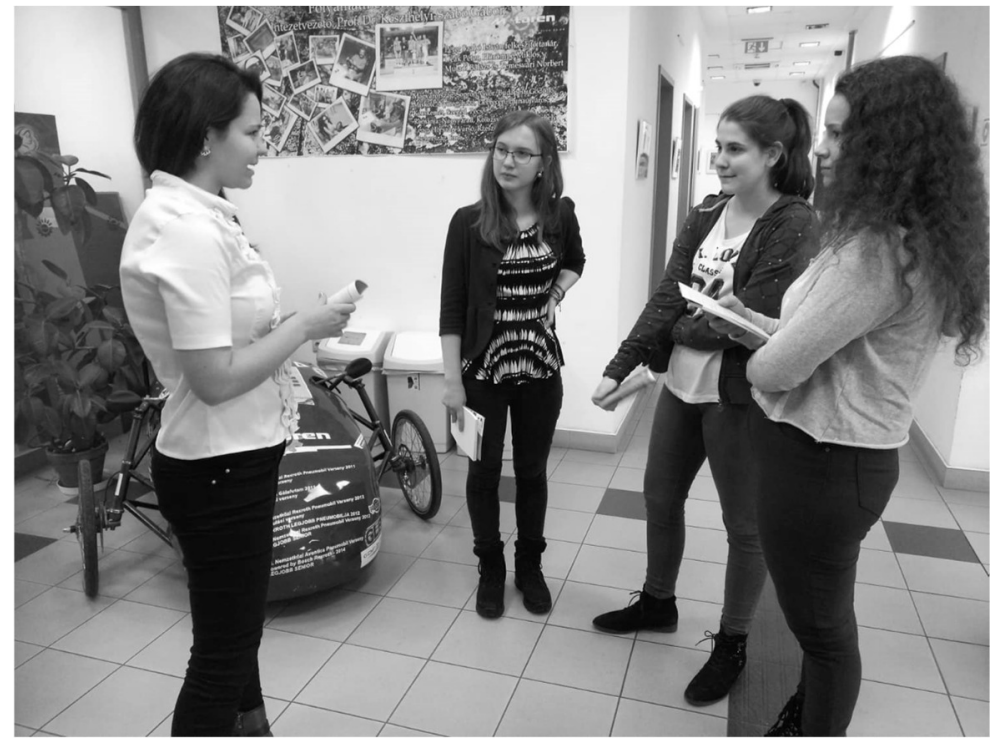

Forrás: A szerzők saját készítésű fényképe.

A középiskolás vendégek érdeklődéssel hallgatták Bencsik Dóra tanársegéd előadását a Dr. Huszka Tibor Élelmiszeripari Szakmai Klub müködéséről (3. ábra).

\section{3. ábra: Előadás a Dr. Huszka Tibor Élelmiszeripari Szakmai Klub} müködéséröl

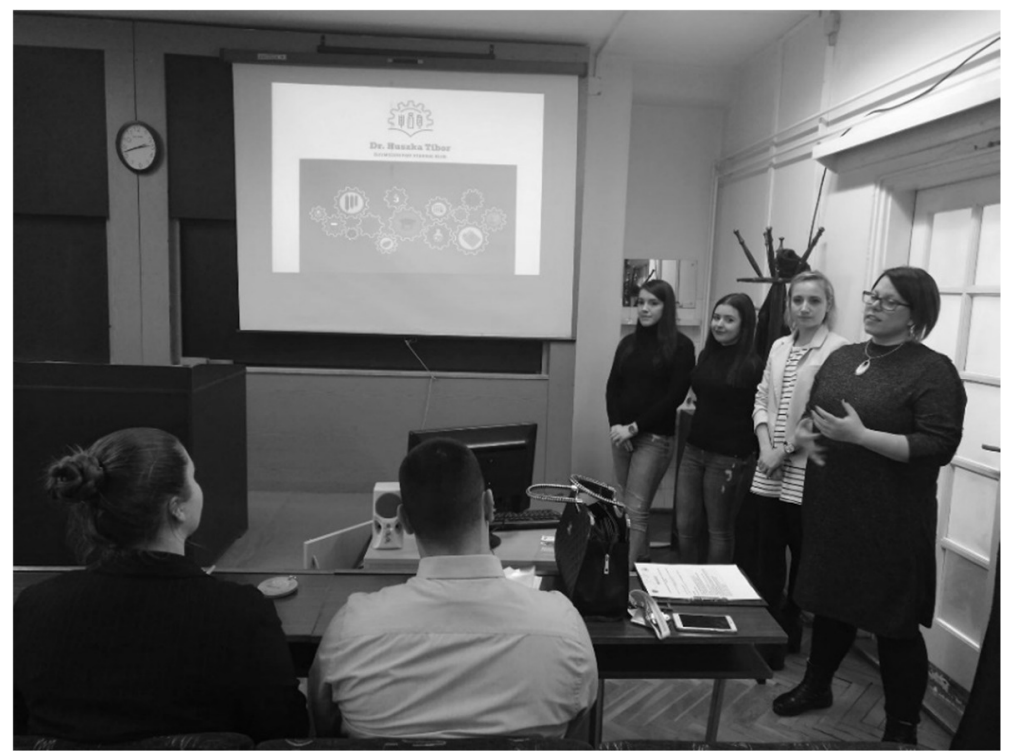

Forrás: A szerzők saját készítésű fényképe. 
A vendég középiskolás lányok Dr. Kertész Szabolcs, tudományos munkatárs (4. ábra), valamint Csikós Sándor egyetemi tanársegéd és Mészáros Attila szakmai szolgáltató irányításával végig látogatták a Mérnöki Kar laborjait.

\section{4. ábra: Labor látogatás}

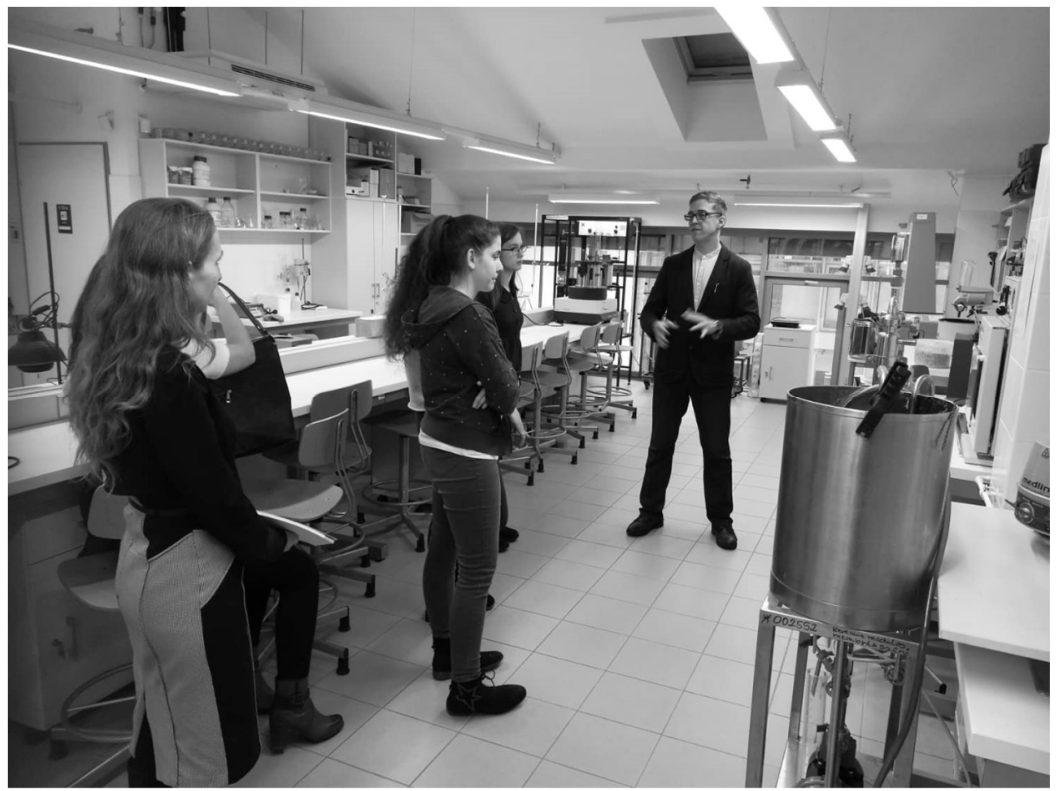

Forrás: A szerzők saját készítésű fényképe.

\section{5. ábra: Pneumobil bemutató}

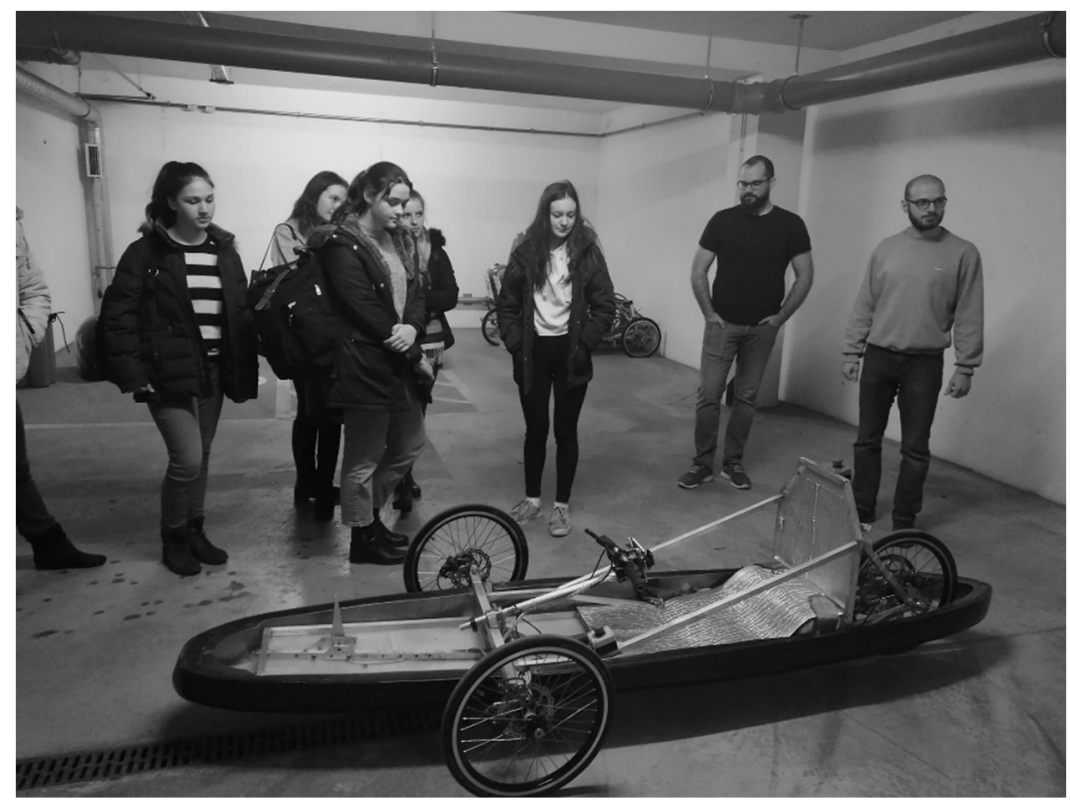

Forrás: A szerzők saját készítésű fényképe. 
Érdeklődést felkeltő, információban gazdag, színes laborvezetést kaptak. Ezeken felül megismerkedhettek a pneumobil autók tervezésével, kivitelezésével (5. ábra).

\section{4. Összegzés}

A vendég középiskolás lányok nem csak végig látogatták a Mérnöki Kar laborjait és betekintést kaptak a kar képzési választékába, hanem rendszeresen visszajárnak konzultálni, kísérleteket végrehajtani a kollégákhoz egyénileg, valamint csoportosan is. Ezen jó kapcsolatot a továbbiakban is szeretnénk fenntartani a helyi középiskolákkal és a Soroptimist Club Szegeddel. Ettől is reméljük, hogy az SZTE MK-n a mérnökhallgató lányok aránya növekedni fog a jövőben.

\section{Köszönetnyilvánítás}

Jelen tanulmány a Szegedi Tudományegyetemen készült AZ Európai Unió támogatásával. Projekt azonosító: EFOP-3.4.3-16-2016-00014.

\section{Irodalomjegyzék}

Fabulya Z. (2004): A digitális kultúra szerepe a gépészmérnök hallgatók müszaki tervezés oktatásában a Szegedi Tudományegyetem Élelmiszeripari Főiskolai Karán: Role of the digital culture in the computer aided design teaching of the students at the University of Szeged College Faculty of Food Engineering. In: Hodúr C., Kovács E., Véha A., Szűcs E. (szerk.): A VI. Nemzetközi Élelmiszertudományi Konferencia elöadásainak és posztereinek összefoglalói: 6th International Conference on Food Science, Szeged, Magyarország. Szegedi Tudományegyetem Élelmiszeripari Főiskolai Kar. 239-240.

Hampel Gy. (2018): Information and Information Systems as Keys to Success. Quaestus Multidisciplinary Research Journal, 13: 71-82.

Kiss M., Kun A. I. (2018):Milyen imázst közvetítenek a magyar felsőoktatási intézmények honlapjai? International Journal of Engineering and Management Sciences/ Müszaki és Menedzsment Tudományi Közlemények, 3 (3): 355-370.

Kiss Zs., Barizsné Hadházi E. (2016): Műszaki diplomások munkerő-piaci sikeressége. International Journal of Engineering and Management Sciences/ Müszaki és Menedzsment Tudományi Közlemények, 1 (1).

Kiss Zs., Barizsné Hadházi E., Kun A. I. (2017): A leendő munkavállalás hallgatói szemmel: egy a Debreceni Egyetem alapszakos hallgatói körében végzett felmérés eredményei. Taylor: Gazdálkodás- és Szervezéstudományi Folyóirat: a Virtuális Intézet Közép-Európa Kutatására Közleményei, 9 (1): 183-190.

Kun A. I. (2018): Intézményválasztás, szakválasztás, szervezeti kultúra a felsőoktatásban. In: Tóth D. A. (szerk.) Az oktatás gazdagsága: Tanulmányok Polónyi István tiszteletére. CHERD, Debreceni Egyetem, Debrecen. 107-115.

Mocan M., Turi A., Ivascu L., Artene A., Feniser C. (2016). Analyzing and Improving Teaching Methods in Higher Education: Case Study on Romania. MakeLearn International Scientific Conference on Management of Knowledge and Learning, Temesvár.

Turi A., Mocan M., Pujol F. X. (2016). Teacher-student perception differences on ethical issues in higher education. 13th International Conference on Efficiency and Responsibility in Education (ERIE), Prága. 592-601. 